also has a facility with the language of the country of assignment. A science officer's primary role will be to serve as an adviser to the Ambassador and his staff in the evaluation of the interaction of science with foreign policy, the assessment of current scientific progress abroad and the enhancement of the liaison between United States and foreign scientists and engineers.

\section{British Scientific Attachés Overseas}

REPLYing to a question in the House of Commons on December 8 regarding scientific attachés, $M r$. G. M. Thomas, Parliamentary Secretary to the Ministry of Works, as representing the Lord President of the Council, said that the British Embassies at Washington, Paris, Bonn and Stockholm had a scientific attaché on their staff. The choice was now being made of a suitable person for scientific attaché to the British Embassy in Moscow and the appointment of scientifie attachés to certain other embassies was under consideration.

\section{Department of Scientific and Industrial Research :} New Five-Year Plan

Mr. Harmar Nicholls, Parliamentary Secretary to the Ministry of Works, speaking on behalf of the Lord President of the Council, announced in the House of Commons on December 19 that expenditure on research by the Department of Scientific and Industrial Research will be nearly doubled in the next five years. Under its second five-year plan, for the period 1959-64, approximately $£ 61$ million will be made available to the Department, compared with $£ 36$ million for the first quinquennium which ends on March 31. By 1963-64 expenditure is planned to reach about $\& 14$ million, excluding the British contribution to the European Organization for Nuclear Research (C.E.R.N.) which will continue to be financed outside the five-year plan. The largest expansion will be in university grants. Postgraduate awards will be increased by about 10 per cent each year, until in 1963-64 some 3,800 students will be receiving grants from the Department for research, and support for special research in universities will amount to $£ 1 \frac{3}{4}$ million per annum.

In support of additional research carried out in the Department's own laboratories, expansion of staff at the rate of about 6 per cent per annum is included in the plan. Grants to the research associations financed jointly by the Department and industry will also be increased to more than $£ 2$ million per annum by the end of the period. It is also proposed that the Ministry of Works shall increase its rate of expenditure on behalf of the Department so as to provide buildings and equipment for the increased staff of its laboratories. The works programme includes the provision of a new laboratory at Crow. thorne, Berkshire, to rehouse the Road Research Laboratory which at present occupies two separate sites a few miles apart, one at Harmondsworth, Middlesex, and the other at Langley, Bucks. The new Road Research Laboratory will include an experimental road system $3 \frac{1}{2}$ miles long.

\section{Public Expenditure on Education}

IN written answers in the House of Commons on December 17, Mr. Geoffrey Lloyd, Minister of Education, said that expenditure by the Ministry and local education authorities, excluding capital expenditure, was expected to be about $£ 46$ million

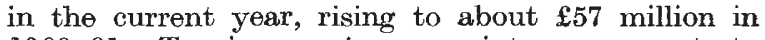
1960-61. To give maximum maintenance grants to 50,000 additional pupils of sixteen and seventeen at the approved rates would cost about $£ 16$ million a year. To reduce all classes to a maximum of thirty by about 1965 would cost about a further $£ 200$ million a year, with some $£ 140$ million on training additional teachers.

\section{Exchange of Personnel between the Post Office and Industry}

ON December 17, the Postmaster-General, Mr. H. Marples, in reply to a question in the House of Commons, said that on January 5, a Post Office administrator and a Post Office engineer would take up temporary appointments with Unilever, Ltd., and two Unilever men would go to the Post Office. The exchange was expected to last about a year, and discussions with another concern were in progress. $\mathrm{He}$ hoped the experiment would be a forerunner of a regular interchange of experience between the Post Office and industry and contribute mutual benefit and a better understanding of each others' problems.

\section{Pharmacology at the Royal College of Surgeons}

The Royal College of Surgeons of England has received a gift of $£ 150,000$ from Mr. G. A. Vandervell for the endowment of its chair of pharmacology. More than ten years have elapsed since those responsible for the rehabilitation of the College after the Second World War recognized that a Department of Pharmacology should be added to the existing departments of anatomy, pathology and physiology, for without it the education of postgraduates in the basic medical sciences would have been incomplete. A still more important objective, however, was the promotion of research into the action of drugs and other substances used not only by surgeons but also by dentists and anæsthetists, who are represented by faculties within the College. The Department was therefore established six years ago, and has flourished under the able direction of Prof. W. D. M. Paton, whose researches into the chemical mediation of nerve impulses are so well known. He and his assistants have been housed temporarily at the Examination Hall, Queen Square, but will shortly be moving into the new buildings in Lincoln's Inn Fields. Since the College is an independent body and therefore does not receive a direct grant from the University Grants Committee or from any other Government source, the Department has been financed hitherto partly by generous contributions from the chemical and pharmaceutical industries. This donation from Mr. Vandervell, which will endow the chair in perpetuity, is doubly welcome since it comes at a time when the College is facing heavy increases in expenditure owing to the extension of its research activities.

\section{National Lending Library for Science and Tech- nology}

ThE Department of Scientific and Industrial Research will take over part of the former Royal Ordnance Factory at Thorp Arch, near Boston Spa, Yorks, for the use of the new National Lending Library for Science and Technology. Present proposals indicate that the library will begin operating. at Thorp Arch in 1961 and become fully operational during the following year. Existing large single-story 